\title{
La naturaleza humanizada en la narrativa de Pío Baroja
}

\author{
Gastón Gaínza \\ Universidad de Costa Rica, Costa Rica \\ comedcic@gmail.com \\ https://orcid.org/0000-0003-2403-6553
}

Recibido: 12 de febrero 2018

Aceptado: 4 de mayo 2018

Resumen:

A partir de los postulados de luri Lotmann, Mijail Bajtin y Feruccio Rossi Landi se establecen algunos nexos con narrativa del escritor español de origen vasco Pío Baroja, particularmente con la novela Zalacaín el aventurero donde se observa la manera mediante la cual Baroja ofrece una perspectiva humanizada de la naturaleza misma.

Palabras clave: Baroja; Lotmann; Zalacaín el aventurero; naturaleza; humanización.

\section{The humanized nature in the narrative of Pío Baroja}

\section{Abstract:}

From the postulates of luri Lotmann, Mijail Bajtin and Feruccio Rossi Landi some links with narrative of the Spanish writer of Basque origin Pío Baroja are established, in a particular way with the novel Zalacaín el aventurero is observed where the way in which Baroja offers a humanized perspective of nature.

Key words: Baroja; Lotmann; Zalacaín el aventurero caves; nature; humanization.

Descubrir el sistema de signos que el ser humano creó para producir textos artísticos es, sin duda, una de las contribuciones más ejemplarizantes de la Escuela de Tartu y de su indiscutible mentor: luri Lotman ${ }^{1}$. Ese lenguaje, al que

\footnotetext{
${ }^{1}$ NAVARRO (1993). Vid., asimismo, LOTMAN (1986) y, muy especialmente, LOTMAN (1975).

(c) (7) (2)

La Revista Estudios es editada por la Universidad de Costa Rica y se distribuye bajo una Licencia Creative Commons Atribución-NoComercial-Compartirlgual 3.0 Costa Rica. Para más información envíe un mensaje a revistaestudios.eeg@ucr.ac.cr.
} 
Especial: Naturaleza amena y naturaleza agreste en las letras hispánicas

llamó "modelizante secundario", les permitió a los colectivos humanos producir, desde sus orígenes, por intermedio de lenguajes primarios, textos sensoriales (auditivos, visuales, táctiles, olfativos y gustativos) que reproducían un modelo de las relaciones sociales en un entorno ficticio.

Aunque esos entornos y actores evocados en el texto correspondan a una fantasía, están condenados a parecerse a los paisajes y las relaciones sociales reales en que el creador vive, pues constituyen el modelo en que este realiza su vida.

Los textos artísticos literarios son productos de este sistema modelizante que se materializa a través de un lenguaje primario que son las diversas lenguas históricas producidas por los colectivos humanos. Por esta razón, un relato y un poema, mantienen su condición aunque se traduzcan a otra lengua diferente de la que, su creador, usó como sistema primario. Son productos artísticos que modelizan unas relaciones sociales en unos entornos semejantes a los que el destinatario reconoce como su propia realidad.

El entorno real de la comunicación está constituido por un 'ahora', un 'aquí' y un 'así'. Estos tres ejes deícticos remiten, respectivamente, al tiempo, el espacio y el consabido histórico de quienes están comunicándose. En definitiva, el entorno que los textos artísticos modelizan, es un lugar en un determinado momento de su existencia y, simultáneamente, en un contexto histórico de las relaciones producidas en el proceso de reproducción social de la existencia real de los grupos humanos ${ }^{2}$.

\footnotetext{
${ }^{2}$ ROSSI-LANDI (1980).

La Revista Estudios es editada por la Universidad de Costa Rica y se distribuye bajo una Licencia Creative Commons Atribución-NoComercial-CompartirIgual 3.0 Costa Rica. Para más información envíe un mensaje a revistaestudios.eeg@ucr.ac.cr.
} 
Especial: Naturaleza amena y naturaleza agreste en las letras hispánicas

De acuerdo con lo dicho hasta aquí, en su condición de productos artísticos, los textos literarios están construidos con los signos y la sintaxis de ese sistema modelizante secundario manifiesto a través de una lengua histórica. Al igual que esta y, precisamente, por su carácter de lenguaje, dicho sistema también posee unidades semánticas mínimas (como las palabras) y reglas de combinación y distribución (como la sintaxis). Los signos más relevantes de la narración literaria son el 'narrador', el 'narratario', los 'personajes', los 'acontecimientos' y el 'cronotopo'3. La combinación de ellos permite construir unidades superiores, como los capítulos de una novela. El cronotopo es el signo que manifiesta el modelo de un entorno, como los que existen en la realidad.

Precisamente, el cronotopo de la novela Zalacaín el aventurero de Pío Baroja ${ }^{4}$ es un buen ejemplo para mostrar les necesarias relaciones entre el arte literario y la biodiversidad. Es la tercera de su trilogía Tierras vascas (la precedieron La casa de Aitzgorri y El mayorazgo de Labraz). Aunque Baroja escribe en castellano, conoció desde su nacimiento (Donostia, 1872) el euskera, la lengua histórica de Euskadi. En la semiosfera ${ }^{5}$ cuyo idioma es el euskera, la relación entre la naturaleza y los seres humanos es determinante, como lo demuestran los apellidos o nombres de familia. Por eso, el narrador creado por Baroja, consciente de que escribe en castellano, se esmera en "traducir" a sus lectores (pertenecientes a otra semiosfera), ese significativo vínculo.

Este rasgo estilístico explica la rigurosa descripción del paisaje en que acontecen las acciones de sus personajes. Ejemplo señero es el "Prólogo" de la novela, que titula "Cómo era la villa de Urbía en el último tercio del siglo XIX":

\footnotetext{
${ }^{3}$ BAJTIN (1986). Passim.

${ }^{4}$ BAROJA (1970).

${ }^{5}$ LOTMAN (1996), pp 21-42
}

La Revista Estudios es editada por la Universidad de Costa Rica y se distribuye bajo una Licencia Creative Commons Atribución-NoComercial-CompartirIgual 3.0 Costa Rica. Para más información envíe un mensaje a revistaestudios.eeg@ucr.ac.cr. 
"Hay todavía, en los fosos, terrenos encharcados con hierbajos y espadañas, poternas llenas de hierros, garitas desmochadas, escalerillas musgosas, y alrededor, en los glacis, altas y románticas arboledas, malezas y boscajes, y verdes praderas salpicadas de florecillas" (Ed. Cit., p. 9).

El inevitable encuentro del protagonista con su tío abuelo Tellagorri, es el inicio de la epopeya de Zalacaín, pues de él aprende a reconocer la naturaleza y, de algún modo, a convertirla en una fuerza acorde con sus propósitos. El aprendizaje de las artes de la pesca fluvial le sirve para reconocer la diferencia de la acción en el terreno y en las riberas de los ríos. Es relevante, por esto mismo, una de las descripciones iniciales del paisaje de la vega del Ibaya:

"En la primavera, el camino próximo al río era una delicia. Las hojas nuevas de las hayas comenzaban a verdear; el helecho lanzaba al aire sus enroscados tallos; los manzanos y los perales de las huertas ostentaban sus copas nevadas por la flor, y se oían los cantos de las malvises y los ruiseñores en las enramadas. El cielo se mostraba azul, de un azul suave, un poco pálido, y solo alguna nube blanca, de contornos duros, como si fuera de mármol, aparecía en el cielo" (Ibid., p. 28).

Muchos otros ejemplos podrían citarse, pero la perspicacia de los lectores me permite omitirlos. Con todo, es imprescindible destacar el vínculo que existe, en el relato, entre la naturaleza y Zalacaín. Aunque la concordancia se muestra en múltiples secuencias del relato, la más representativa es, en mi opinión, la que narra la conversación que sostiene Martín con el "extranjero", ese personaje periodista que el narrador introduce como referente de alteridad (Ibid., Cap. V del Libro II).

\section{(C) $(00$}

La Revista Estudios es editada por la Universidad de Costa Rica y se distribuye bajo una Licencia Creative Commons Atribución-NoComercial-CompartirIgual 3.0 Costa Rica. Para más información envíe un mensaje a 
Especial: Naturaleza amena y naturaleza agreste en las letras hispánicas

Durante el paseo nocturno que ambos realizan (para evitar dormir en la asquerosa venta en que habían hallado espacio en Estella) ${ }^{6}$, escuchan a la soldadesca cantar jotas. Esto le recuerda a Martín ese "hombre viejo, bajito, que presidía las mesas" que, después de obligar a todos a rezar antes de comer, se pone a contar, con ánimo festivo, unas repulsivas historias de sus matanzas de liberales. Llegan, en ese momento, junto a un casino en el que están otros hombres jugando. Entonces, se produce el siguiente diálogo:

“--Juego, campanas, carlismo y jota. ¡Qué español es esto, mi querido Martín! -dijo el extranjero.

--Pues yo también soy español, y todo eso me es muy antipático -contestó Martín.

--Sin embargo, son los caracteres que constituyen la tradición de su país -dijo el extranjero.

--Mi país es el monte -contestó Zalacaín" (Ibid., p. 103. Subrayado mío).

El título de esta ponencia caracteriza como "humanizada" la naturaleza que el novelista vasco describe en sus relatos. Mi intención era señalar que en muchas de esas descripciones existe un afán por traducir la vivencia del paisaje desde la semiosfera del euskera a la del castellano. Y la traducción es, en mi criterio, la más humana de todas las capacidades de nuestra especie.

Aunque, en algunos casos, el cronotopo evocado es hostil; como cuando Martín, en el segundo capítulo de "Las últimas aventuras", regresa a Urbía y encuentra la casa de Catalina destrozada. El narrador apunta entonces "en la huerta, abandonada, las lilas mostraban sus ramas rotas, y una de las más grandes, de un magnífico tilo, desgajada, llegaba hasta el suelo. Los rosales trepadores, antes tan lozanos, se veían marchitos" (Ibíd., p. 142).

${ }^{6}$ Ciudad que, en el relato, está en manos de los carlistas.

\section{(c) (i) (-)}

La Revista Estudios es editada por la Universidad de Costa Rica y se distribuye bajo una Licencia Creative Commons Atribución-NoComercial-CompartirIgual 3.0 Costa Rica. Para más información envíe un mensaje a revistaestudios.eeg@ucr.ac.cr. 
Esta descripción del paisaje ilustra los desastres de la guerra (la tercera de las llamadas carlistas, tristes precedentes de la guerra civil iniciada en 1936. Podría hablarse de un intertexto de. Goya).

\section{REFERENCIAS BIBLIOGRÁFICAS}

Bajtin, Mijaíl M. (1986): Problemas literarios y estéticos. La Habana: Arte y Literatura. Trad.: Alfredo Caballero.

Baroja, Pío (1970): Zalacaín el aventurero. Historia de las buenas andanzas y fortunas de Martín Zalacaín de Urbía. Madrid: Espasa-Calpe, 6a. Ed. Col. Austral, 346.

Escritos, No. 9 (enero-diciembre de 1993). Editor invitado: Desiderio Navarro. [Revista del Centro de Ciencias del Lenguaje. Benemérita Universidad Autónoma de Puebla, México.]

Lotman, luri (1975): La structure du texte artistique. Paris: Éd. Gallimard. Préface: Henri Meschonnic. Trad. Du russe: Éve Malleret et Joëlle Yong sous la direction d'Henri Meschonnic. Bibliothéque des Sciences Humaines.

Lotman, I. (1986): "Los estudios literarios deben ser una ciencia". En NAVARRO (Comp.), Vol. I, pp. 73-86.

Lotman, I. (1996): La semiosfera. Semiótica de la cultura y el texto. Madrid: Ed. Cátedra. Selección y traducción del ruso: Desiderio Navarro. Con un capítulo final de Manuel Cáceres. Col. Frónesis.

Navarro, Desiderio (Compilador) (1986): Textos y contextos. Una ojeada en la teoría literaria mundial, 2 Vols. La Habana: Edit. Arte y Literatura.

Navarro, D. (1993): "Mostrar la Escuela de Tartu como escuela más allá de Lotman y Uspenski". En: Escritos, No. 9; pp. 7-13.

Rossi-landi, Ferruccio (1980): Ideología. Barcelona: Ed. Labor.

\section{(c) (i) (2) (2)}

La Revista Estudios es editada por la Universidad de Costa Rica y se distribuye bajo una Licencia Creative Commons Atribución-NoComercial-CompartirIgual 3.0 Costa Rica. Para más información envíe un mensaje a 